\title{
Die Verskynsel van Gesinne wat betrokke is by Besluitneming oor Onttrekking van Lewensondersteunende
}

Behandeling

\author{
M. Oberholster \\ M Cur (Psigiatriese Verpleegkunde) \\ RAU \\ \& \\ A Gmeiner \\ D Cur (Psigiatriese Verpleegkunde)
} RAU

\&

\section{Poggenpoel \\ D Phil (Psigiatriese Verpleegkunde) \\ RAU}

\section{"Die situasie kom voor waar die pasiënt en sy familie wat die besluit moet neem aangaande die onttrekking van lewensondersteunde behandeling, aan uiters morele konflik blootgestel word."}

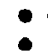

-

-

-

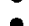

-

-

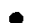

$\bullet$

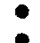

-

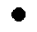

-

\section{Opsomming}

Die oorkoepelende doel van die studie was om die verskynsel van gesinne wat betrokke is by besluitneming oor onttrekking van lewensondersteunende behandeling te verken en te beskryf. Die verskynsel analise was in twee fases gedoen. In fase een is sekondêre analise van primêre data gedoen van 'n gesin uit Burger (1996:1-175) se studie en opgevolg met fenomenologiese onderhoude met lidkontrole gesinne wat as datakontrole gedien het. Die analise van data is gedoen in samewerking met ' $n$ onafhanklike kodeerder. Hierna is literatuurkontrole bygewerk. Temas wat geïdentifiseer was, is: Fisieke en liggaamlike belewenisse van gesinne rondom die besluitneming oor onttrekking van lewensondersteunende behandeling; verdedigingsmeganismes deur gesinne gebruik as wyse om pyn en hartseer te hanteer; emosionele belewenisse van gesinne rondom besluitneming van onttrekking van lewensondersteunende behandling; behoefte aan kennis/persepsies/ lewensbeskouings/interne konflik / skuldgevoelens/vermoë of onvermoë om ' $n$ besluit te neem/respek vir pasiënt wense / die rol van tyd en vorige ervaring; ondersteuning ontvang en benodig deur gesinne wat betrokke is by besluitneming oor onttrekking van lewensondersteunende behandeling; geestelike en mistieke belewenisse/hoop/berusting en aanvaarding / vermoë om 'te laat gaan' of 'los te makk' van die pasiënt. In fase twee is uit al die bogenoemde data riglyne vir die psigiatriese verpleegspesialis beskryf om hulpbronne te mobiliseer vir gesinne ter bevordering, handhawing en herstel van hulle geestesgesondheid as integrale deel van gesondheid.

\section{Summary:}

The overall objective of this study was to explore and describe the phenomenon of families who are involved in deciding about withdrawal of life-support treatment of a family member. A phenomenon analysis was undertaken in two phases. During the first phase, secondary analysis of primary data was done on the family used in Burger's study (1996:1-175) and was followed up by phenomenological interviews with families used as member checking from the same circumstances and according to the same criteria that Burger (1996:1$185)$ used in her study. Data were analysed in collaboration with an independent coder. The family used as member checking in this study is also used as data control. A literature control was conducted as part of data control. The themes that were identified included were: physical and bodily experiences of families; defence mechanisms used by families to cope with grief; emotional experiences of families; need of knowledge / perceptions / outlook on life / internal conflict / feelings of guilt/ ability to make decisions / respect of patient wishes / the effect of time and prior experiences; support needed by an given to families; spiritual and supernatural experiences / hope / acceptance / ability to 'let go' of the patient. In phase two, guidelines were described for psychiatric nurse specialists to mobilise resources for families to promote, maintain and restore their mental health as an integral part of health. 


\section{Inleiding en Probleemstelling}

Min studies is nog gedoen wat die gesin in besluitneming oor lewensondersteunende behandeling betrek. Die studies wat wel gedoen is, was meer gerig op lede van die gesondheidspan, hul opinies, blootstelling, houdings, onderrig en besluitnemingsprosesse. Die pasiënt en sy familie is nie ingesluit nie. Die outonomie van die pasiënt word toenemend belangrik (Strauss, 1993: 198). Die gesondheidspan kan nie meer besluite namens die pasiënt neem oor wat reg of verkeerd is nie - die pasiënt beskik oor sy eie liggaam en lewe. In die intensiewesorgeenheid gebeur dit egter dikwels dat die pasiënt nie tot aktiewe deelname aan die besluitnemingsproses kan deelneem nie as gevolg van die aard van sy ongesteldheid en/of medikasie. Die familie tree dan na vore as besluitnemers omdat die finansiële las om vir die behandeling te betaal, dikwels op hulle geplaas word. Dit is tans die gebruik om die familie in sulke situasies in te sluit as "spreek- buis" van die pasiënt (Burger, 1996:1-175).

Die situasie kom nou voor waar die pasiënt en sy familie wat die besluit moet neem aangaande die onttrekking van lewensondersteunde behandeling, aan uiters morele konflik blootgestel word. Volgens Morris (1992:223) is die gevolge skuldgevoelens, berou, selfverwyt, afgryse, wanhoop en woede.

Burger (1996:163) is in haar studie diep onder die indruk gebring van die geweldige pyn wat die familie ervaar wat voor sulke keuses gestel word. Volgens haar is ' $n$ familie wat sulke traumas beleef, nie in staat om te fokus en inligting te verwerk nie. Hulle ervaar groot behoefte aan iemand wat hulle kan ondersteun. Die intensiewesorg verpleegkundige kan dit volgens haar, om verskeie redes, nie doen nie. Een van die redes is beperkte tyd, onvermoë om ' $n$ terapeutiese verhouding op te bou, is ' $n$ ander rede. Sy beveel aan dat verdere studies oor die emosionele aspekte rondom besluite van hierdie sensitiewe aard onderneem word - nie net deur die intensiewesorg verpleegkundige nie maar ook deur die psigiatriese verpleegkundige.

Om effektiewe ondersteuning aan die gesin in hierdie omstandighede te kan bied, was dit eerstens vir die psigiatriese verpleegkundige nodig om te verken wat die belewenisse / ervaringe is wat ' $n$ rol speel by die besluit oor onttrekking van lewensondersteunende behandeling. Dit kan dan dien as bais om riglyne te beskryf vir die psigiatriese verpleegspesialis om hulpbronne vir die gesin te mobiliseer ter bevordering, handhawing en herstel van hulle geestesgesondheid as integrale deel van gesondheid.

Uit bogenoemde is die volgende navorsingsvrae gevra:

Hoe lyk die verskynsel van gesinne wat betrokke is by besluitneming oor onttrekking van lewensondersteunende behandeling by ' $n$ lid van die gesin?

Watter riglyne kan gestel word vir die psigiatriese verpleegspesialis om hulpbronne te mobiliseer vir gesinne ter bevordering, handhawing en herstel van hulle geestesgesondheid as integrale deel van gesondheid?

\section{Doelstellings}

Hierdie studie het ten doel gehad:

Die verkenning en beskrywing van die verskynsel van gesinne wat by besluitneming oor onttrekking van lewensondersteunende behandeling by ' $n$ lid van die gesin betrokke is.

Die beskrywing van riglyne vir die psigiatriese verpleegspesialis om hulpbronne te mobiliseer, wat sal bydra tot die bevordering, handhawing en herstel van die gesin se geestesgesondheid as integrale deel van hul gesondheid.

\section{Navorsingsmodel en Paradigmatiese Perspektief}

Botes (1989:1-283) se navorsingsmodel is as uitgangspunt in hierdie studie gebruik. Die studie was vanuit 'n JudeoChristen perspektief gedoen volgens die Verplegingsteorie vir Mensheelheid (Oral Roberts University, Anna Vaughn School of Nursing, 1990:136-142).

Vanuit die Verplegingsteorie vir Mensheelheid was die aannames met betrekking tot die gesin aanvaar en het dit as fokus gedien vir die formulering van ' $n$ sentraal teoretiese stelling, naamlik: Begrip van die verskynsel van gesinne wat betrokke is by besluitneming oor onttrekking van lewensondersteunende behandeling, kan as basis dien vir die beskrywing van riglyne vir die psigiatriese verpleegspesialis om hulpbronne te mobiliseer vir dié gesinne ter bevordering, handhawing en herstel van hulle geestesgesond. heid as integrale deel van hul gesondheid.

\section{Navorsingsontwerp en -Metode}

'n Kwalitatiewe, verkennende, beskrywende en kontekstuele studie is onderneem (Burns \& Grove, 1993: 27; 1994: 2-
27). Kwalitatiewe navorsing word beskryf as ' $n$ subjektiewe benadering om lewensondervindinge te beskryf en betekenis daaraan te gee. Hierdie benadering bevorder die begrip van die geheel, wat ook kongruent is aan die Verplegingsteorie vir Mensheelheid (Oral Roberts University, Anna Vaugh School of Nursing, 1990: 136-142).

Hierdie studie het in twee fases geskied. In fase een is gebruik gemaak van sekondêre data-anlise deur die inligting deur Burger (1996:1-175) bekom is, te herevalueer en analiseer, op soek na temas wat betrekking het op die verskynsel van gesinne wat betrokke is by besluitneming ooronttrekking van lewensonderdteunende behandeling. Daarna is fenomenologiese onderhoude met lidkontrole gesinne in ' $n$ soortgelyke situasie en omgewing gedoen ter ondersteuning en kontroleringvan bogenoemde temas. Veldnotas en waarneming is deurentyd gebruik. Audiobande is deur myself en ' $n$ onafhanklike kodeerder, wat ' $n$ kenner op die gebied van kwalitatiewe navorsing is, geanaliseer om te bepaal watter geestegesondheidsimplikasies tydens besluitneming na vore kom vir hierdie gesinne in hulle strewe na geestesgesondheid

Data is geanaliseer deur gebruik te maak van die beskrywende metode van data analise soos deur Tesch (in Creswell $1994: 155)$ beskryf. Hierna is ' $n$ literatuurkontrole gedoen om die bevindinge van die studie te vergelyk met bestaande data uit soortgelyke studies ( Burns \& Grove, 1993:141).

Hierna is in fase twee riglyne vir psigiatriese verpleegspesialiste beskryt om hulpbronne te mobiliseer vir dié gesinne ter bevordering, handhawing en herstel van hulle geestesgesondheid as integrale deel van hul gesondheid, op grond van alle inligting wat verkry is. Riglyne is met deskundiges in die psigiatriese praktyk / veld, sowel as met lidkontrole gesinne bespreek. ' $n$ Literatuurkontrole is daarna uitgevoer om riglyne aan te vul en te vergelyk met bestaande data en soortgelyke studies (Burns \& Grove, 1993: 141; Zeelie, 1994 28-29).

\section{Steekproef}

Omdat Burger (1996:1-175) se studie as vertrekpunt geneem is vir hierdie navorsingstudie, was dit belangrik dat die deelnemers geselekteer sou word volgens die spesifieke kriteria wat sy in haar studie gestel het. Gesinne was volgens die kriteria gesellekteer word totdat die data versadig is soos gereflekteer in herhalende temas (Burns \& Grove, 1993: 246-247). Die steekproef in hierdie studie was doelgerig gekies (Seaman 1987: 224), naamlik gesinne 
van pasiënte in privaat hospitale in die Kaap en Johannesburg wat aan die volgende kriteria voldoen het (Burger 1996: 31-32):

- Die pasiënt moes kritiek siek wees en dus omvangryke, intensiewe en uitgebreide behandeling ontvang, soos byvoorbeeld, inotropiese ondersteuning meganiese ventilasie en/of nierdialiese.

- $\quad$ Die geneeshere betrokke by die pasiënt moes hul onsekerheid oor die pasiënt se prognose uitspreek.

- Die pasiënt (en die gesin) moes Afrikaans of Engels magtig wees ter wille van veral onderhoudvoering.

- Die pasiënt moes van Westerse kultuur wees sodat die navorser sy kulturele waardes kan verstaan en in terme van die konteks kon interpreteer (kruiskulturele toetsing is nie die doel van die studie nie).

- Die bewussynvlak van die pasiënt was nie in oorweging by insluiting nie, omdat die meeste pasiënte in hierdie situasie onbewus was van hulle omgewing.

- Die betrokkenes moes almal toestemming tot deelname gee. Dit impliseer dat die pasiënt (indien hy/sy by sy/haar bewussyn was) en sy gesin bewus moes wees van die moontlikheid dat behandeling onttrek kon word.

\section{Vertrouenswaardigheid}

Vertrouenswaardigheid sal verseker word deur die gebruik van Guba se model, soos beskryf deur Krefting (1991:215-217) wat op die volgende gebaseer is : Die waarheidswaarde sal bepaal of, en in watter mate, bedreigings vir interne geldigheid beheer is, asook die geldigheid van die instrument as meting van die verskynsel, in hierdie geval die navorser as instrument. Toepaslikheid sal bepaal word, naamlik of bevindinge na ander populasies veralgemeen kan word, in hierdie navorsing verwys dit na oordraagbaarheid. Konstantheid sal beraam word, dit wil sê of dieselfde resultate verkry sou word as die studie in die selfde omstandighede met dieselfde teikengroep herhaal sou word. Daar sal geëvalueer word of prosedures en resultate vry is van navorsers vooroordeel, met ander woorde neutraal, is. (Tabel 1 gee 'n opsomming van die strategieë om vertrouenswaardigheid te verseker).

\section{Bespreking van Resultate}

Die verskynsel van gesinne wat betrokke is by die besluitneming oor onttrekking van lewensondersteunende behandeling by ' $n$ lid van die gesin, is volgens verskillende temas bespreek.

\section{Die feit dat die pasiënt (as persoon) nie meer dieselfde was en gelyk het en met die gesin kon kommunikeer nie, het dit vir van die gesinslede moeilik gemaak om die pasiënt te besoek en 'n besluit oor onttrekking van behandeling te maak.}

Die temas wat ter sprake is, is bloot ' $n$ kunsmatige skeiding van vervlegte data Kategorisering van temas help egter met die logiese uiteensetting van data. Hierdie temas sluit in: fisieke en liggaamlike belewenisse rondom besluitneming; verdedigingsmeganismes deur die gesin gebruik as wyse om pyn en hartseer te hanteer; emosionele belewenisse van die gesin rondom die besluitneming; behoefte aan kennis / persepsies / lewensbeskouings / interne konflik / skuldge -voelens / vermoë of onvermoë om te beluit / respek vir pasiënt se wense / die rol van tyd en vorige ervaring; ondersteuning ontvang en benodig deur die gesin in die proses van besluitneming; en geestelike en/of mistieke belewenisse, vermoë om 'los te maak' hoop, berusting en aanvaarding.

Gesin 1: Die gesin uit die sekondêre analise bestaan uit die pasiënt, ' $n$ huisvrou van 55 jaar oud wat woon op 'n plattelandse dorp wat ongeveer twee uur se ry vanaf Johannesburg, waar sy in die intensiewesorgeenheid lê; haar man, 55 jaar oud en 'n gewese passer en draaier wat drie jaar gelede afgetree het. Hulle het vier kinders: 1 ste dogter, 30 jaar oud, woon in Johannesburg, die moeder van twee kinders; 2de dogter, 28 jaar oud, woon in die selfde dorp as haar ouers, getroud, met twee kinders; 'n seun, 26 jaar oud, woon in die selfde dorp as sy ouers, getroud, met een kind; 3de dogter, 24 jaar oud, woon in die selfde dorp as haar ouers, getroud, een kind. Onderhoude is met die man en dogters deur Gloria Burger (1996: 1-175) gevoer.

Die lidkontrole gesin wat vir hierdie studie gebruik word, gesin 2: Die gesin bestaan uit die pasiënt, 'n afgetrede hoë offisier in die polisie, 67 jaar oud en woonagtig in die Kaapprovinsie; sy vrou, 'n 60 jarige huisvrou; hulle dogter, 37 jaar oud, woonagtig in Gauteng, met een kind; en hulle seun 36 jaar oud, woonagtig in die Oranje Vrystaat, getroud met twee kinders. Onderhoude kon net met die vrou en dogter gevoer word. Die onderhoude is op oudio band geneem, woord vir woord getranskribeer en geanaliseer volgens die protokol soos gebruik met die sekondêre analise.

\section{Fisieke en liggaamlike} belewenisse van die gesin rondom die besluitneming
Verontwaardiging en ontnugtering oor die liggaamlike toestand van die pasiënt word deur verskeie van die gesinslede uitgespreek: '...hy't ontsettend, hy het so sleg gelyk... ek het geskrik. Hy was geweldig geswel, hy was onherkenbaar geswel...'

Die feit dat die pasiënt (as persoon) nie meer dieselfde was en gelyk het en met die gesin kon kommunikeer nie, het dit vir van die gesinslede moeilik gemaak om die pasiënt te besoek en ' $n$ besluit oor onttrekking van behandeling te maak. Die pasiënt se man vertel: 'Die seun en ander dogter wil nie kom nie. Hulle kan dit nie verdra om haar so te sien nie. Hulle is te lief vir haar...'

Czerwiec (1996: 35) vind dat gesinslede en vriende het ' $n$ ander beeld van hulle geliefde en ervaar dikwels skok of droefheid as hulle nog nie vrede gemaak het met die toestand of diagnose van die pasiënt nie.

Gesinslede en pasiënte in hierdie studie ervaar ook ' $n$ behoefte aan nabyheid met mekaar en toon hulle liefde deur fisiese kontak. ' $n$ Pasiënt skryf: 'Wanneer is besoektye? Roep my man!' en 'Waar is die kinders?' Die vrou van 'n pasiënt noem ook: '...ek het met hom gepraat en aan hom gevat en sy hare gestreel elke keer as ek daar kom...'

Van die gesinslede wil graag deel wees van die versorging van die pasiënt. ' $n$ Dogter noem dat sy baie vies was omdat hulle as familie altyd uitgestuur word as daar met haar ma gewerk word. Sy wil ook deel wees van die versorging en wou sien dat haar ma nie pyn het nie.

Gesinslede is ook baie sensitief vir die pasiënt se behoeftes en ontnugter in die feit dat nie al die personeel dit in ag neem nie. ' $n$ Dogter noem: 'Weet jy wat my ma ontstel? Daardie 'male nurse'. Sy lê daar kaal... toe hy haar klaar gebad het, toe ek inkom, toe sê sy vir my: ek soek my klere...' Thompson (1979:39) noem ook dat die gebrek aan begrip vir die behoefte vir privaatheid in die hospitaal wanneer iemand sterwend is, 'n saak van kommer vir die geliefdes was.

Die belangrikheid van goeie sorg word weerspieël in gesinslede se dankbaarheid teenoor personeel wat moeite met 


\begin{tabular}{|c|c|c|c|}
\hline $\begin{array}{l}\text { Kriteria om vertrouens- } \\
\text { waardigheid te verseker }\end{array}$ & Strategie & Kriteria & Toepassing \\
\hline Waarheidswaarde & Geloofwaardigheid & $\begin{array}{l}\text { Verlengde betrokkenheid } \\
\text { Refleksiewe analise } \\
\text { Triangulering } \\
\text { Strukturele verbandhouden- } \\
\text { heid } \\
\text { Leduurgroep ondersoek } \\
\text { Pontrole }\end{array}$ & $\begin{array}{l}\text { - Sekondêre analise van rou } \\
\text { primêre data uit Burger (1996) } \\
\text { - Fenomenologiese onderhoude } \\
\text { met lidkontrole gesinne totdat } \\
\text { data versadig is en die neem van } \\
\text { veldnotas } \\
\text { - Neem van veldnotas tydens } \\
\text { onderhoude } \\
\text { - Data-insameling vind plaas } \\
\text { deur } \\
\quad \text { - sekondêre analise } \\
\quad \text { - onderhoude } \\
\quad \text { - veldnotas } \\
\text { - Dataverwerking vind plaas deur } \\
\text { twee kodeerders onafhanklik van } \\
\text { mekaar } \\
\text { - Literatuurkontrole } \\
\text { - Respondente sal gevra word } \\
\text { om te kontroleer of belewenisse } \\
\text { korrek geinterpreteer is } \\
\text { - Literatuurkontrole oor belewe- } \\
\text { nisse van gesinne in soortgelyke } \\
\text { situasies } \\
\text { - Onafhanklike kodeerder word } \\
\text { gevra om kodering te doen } \\
\text { plegingsteorie vir mensheelheid }\end{array}$ \\
\hline Toepaslikheid & Oordraagbaarheid & Volledigheid van beskrywing & $\begin{array}{l}\text { - Volledige beskrywing van meto- } \\
\text { dologie, literatuurkontrole asook } \\
\text { transkripsie van onderhoude } \\
\text { - Riglyne vir psigiatriese verpleeg- } \\
\text { spesialiste sal ook volledig } \\
\text { bespreek word }\end{array}$ \\
\hline Konstantheid & Vertroubaarheid & $\begin{array}{l}\text { Deeglike beskrywing van } \\
\text { Koderings-herkoderings- } \\
\text { prosedure } \\
\text { Triangulering } \\
\text { Portuurgroep-ondersoek }\end{array}$ & $\begin{array}{l}\text { - Metodologie van die studie sal } \\
\text { volledig bespreek word } \\
\text { - Konsensus gesprekke word } \\
\text { deur navorser en kodeerder } \\
\text { gevoer - volgens Tesch prosedure } \\
\text { - Sekondêre analise, lidkontrole, } \\
\text { veldnotas en literatuurkontrole } \\
\text { - Navorsing word met studie- } \\
\text { leiers as deskundiges op dié } \\
\text { gebied asook met ander } \\
\text { psigiatriese verpleegspesialiste } \\
\text { bespreek }\end{array}$ \\
\hline Neutraliteit & Bevestigbaarheid & $\begin{array}{l}\text { Bevestigbaarheid } \\
\text { Triangulasie } \\
\text { Refleksiewe analise }\end{array}$ & $\begin{array}{l}\text { - Riglyne vir die psigiatriese } \\
\text { verpleegspesialis om hulpbronne } \\
\text { vir die gesin te identifiseer sal aan } \\
\text { hulle en lidkontrole gesinne } \\
\text { voorgelê word om die mate van } \\
\text { bevestigheid te bepaal } \\
\text { - Soos hierbo bespreek } \\
\text { - Soos hierbo bespreek }\end{array}$ \\
\hline
\end{tabular}


pasiëntsorg doen: '...Dit is een van die beste susters wat haar kon verpleeg het. Jy weet, as jy daar inkom dan het hy haar gedraai. Jy weet, hy het haar elke keer gemaklik gemaak op ' $n$ ander manier...' en '...hulle het so mooi na haar gekyk...'

Dit is ook belangrik vir gesinslede om seker te maak dat die pasiënt goed versorg word en nie pyn en lyding ervaar nie. Gesinslede wil ook tot op die laaste die pasiënt se wense uitvoer en sy/haar gemak verseker. Gesinslede in die studie gee ooknegatiewe terugvoer oor sorg en behandeling: 'Dis net een suster gewees wat vreeslik ongeduldig was met haar. Sy was baie ongeskik gewees. Sy was regtig, sy het nie geduld gehad nie...'

Gesinslede in Czerwiec (1996:32-36) se studie, dui ook die pasiënt se fisiese gemak en sorg as die mees belangrikste punt aan. Meeste negatiewe kommentaar kom ook van gesinslede wat ontsteld is oor die manier wat die pasiënt behandel is.

Die feit dat die pasiënt in die intensiewe eenheid aan kunsmatige masjiene gekoppel was, het gesinslede deur hulle ontkenning van die erns van die pasiënt se siekte toestand hulself bereid verklaar vir eie liggaamlike opofferinge: ' $K y k$, al wat ek die heel tyd gesê het is:sy het vier kinders, as haar niere gaan staan het kan een van ons ' $n$ nier gee...' Hierteenoor besef ander gesinslede ook die beperkinge op die mediese tegnologie: ...Dit help nie om my pa byvoorbeeld soos wat die dokter gesê het op die niermasjien te sit nie. Dit gaan net sy lyding verleng...

Kirschbaum (1996:67) noem in sy studie ook dat sommige ouers uit desperaatheid gekyk het na enige tegnologie, omdat hulle oortuig was dat gesondheidsdiensverskaffers hulle kind kon "fix" en was verbaas om beperkinge op tegnologiese gebied tee te kom.

Gesinslede uit beide gesinne ervaar liggaamlike ontberinge in die tydperk wat hulle die pasiënt in die intensiewesorgeenheid besoek: '...vir vier weke het ek soggens, middae en in die aande, maar ek het later die oggende uitgesny, want ek het gesien hulle (personeel) is besig... ek was natuurlik net baie moeg van die ry heen en weer...'

Die gesinne beleef ook fisieke ongemak en ontwrigting van hulle huislike lewens. ' $n$ Dogter vertel dat haar pa by haar kom bly het vir dié tydperk. Dit het beteken dat sy vir ' $n$ paar weke hom elke dag hospitaal toe moes aanry in verkeer en elke dag ' $n$ kosmandjie met koffie en ander verversings moes pak en nog self ook steeds weeksdae gaan werk.
Gesinslede wat ver van die hospitaal woon en vir besoeke na die pasiënt in die intensiewesorgeenheid kom noem van hulle ontberinge. 'Jy kom van ver af in Johannesburg toe... Nou kom jy reguit hospitaal toe... Waar gaan iy met die kinders heen? Dit is vir hulle net so ' $n$ ontwrigting soos vir almal...'

Lede van die gesin beleef personeel wat hulle buite besoektye toelaat en spesiale moeite doen om hulle tyd wat hulle waak by die pasiënt so gemaklik moontlik te maak, baie positief. Czerwiec (1996:36) noem dat baie respondente spreek hulle dankbaarheid uit teenoor verpleegkundiges wat hulle as gesin ook 'versorg' het.

Op finansiële gebied word ook ekstra eise aan gesinne gestel wanneer ' $n$ lid van die gesin in die intensiewesorgeenheid lê: '...Jy weet as ek 'n naweek nie geld gehad het nie, iewerste het ons 'n plan gemaak, maar ons het in Johannesburg uitgekom...'

Dit blyk dat lede van die gesin wat die erns van die siekte toestand van die pasiënt ontken, ook ontken dat daar finansiële probleme kan wees. Dit is duidelik dat die mediese onkostes ' $n$ groot bedrag beloop en ' $n$ moontlikheid van probleme kon wees, aangesien die gesin ' $n$ sekere persentasie van die mediese kostes moes dra. Tog was dit baie duidelik vir my en die onathanklike kodeerder dat dit nie die besluitneming oor onttrekking van behandeling by die gesin beinvloed het nie. ' Jy weet, wat vir ons belangrik was, was my ma se gesondheid...' Cantor (1987:87-90) vind dat familie en vriende somtyds onderworpe is aan erge emosionele en ekonomiese druk tydens ' $n$ geliefde se verlengde sterwensproses

\section{- Verdedigingsmeganismes deur die gesin gebruik as wyse om pyn en hartseer te hanteer}

Uit analise van die data van die gesinne het dit my en die onafhanklike kodeerder opgeval dat in beide gevalle het die pasiënte soos die gesinslede ook van verdedigingsmeganismes gebruik gemaak om die werklikheid/waarheid van hulle siekte toestand te vermy en ontken. Die pasiënt se vrou vertel: '...toe sê ek, maar as jy só siek is moet ons 'n dokter laat kom. Ek bel die dokter. Toe sê hy: Nee. Dit sal regkom en hy's okay....' Beauchamp \& Perlin (1978:142) vind dat pasiënte is in verskillende stadiums van die sterwensproses bewus van die erns van hulle siekte toestand, of hulle vertel word of nie.

Amper al die gesinslede maak van ontkenning gebruik in een of ander stadium van die besluitnemingsproses.
Een van die dogters ontken en vermy so sterk dat sy selfs kwaad word as daar met haar pa gepraat word oor die moontlikheid van besluitneming oor onttrekking van behandeling. 'Ek het geglo tot vier minute voor sy dood is, het ek geglo my ma gaan daar uitkom.... en dan sê die susters vir my pa: jou vrou is siek, sy gaan dit nie maak nie. Laat die dokters die medisyne stop... Toe sê ek vir my pa: as die dokter nie vir pa iets sê nie, dan glo jy nie wat sê 'n suster nie, byt net vas. Sy sal regkom...'

Edwards (1994:53) noem hoe meer kere lede van die gesin die pasiënt sien in sy/ haar toestand, byvoorbeeld komateus, hoe groter is die kans dat hulle ontkenning sal ophef en die realiteit van die situasie sal insink. Soos wat 'n pasiënt se vrou vertel: 'Dit was beslis nie lekker om hom so siek te sien nie, maar later van tyd, in 'n mate, word jy gewoond aan... aan dit... dit wat jy sien, jy weet. Jy kom daar en jy weet presies hoe hy lyk en jy weet presies wat jy daar gaan kry...'

Ook interne konflik kom voor by gesinslede sodat hulle worstel met die 'onaanvaarbare' situasie wat hulle beleef en skryf hulle hulle woede en gedagtes en impulse aan ander toe deur van projeksie gebruik te maak. So projekteer 'n dogter haar eie warboel van gevoelens as sy sê: '...die susters het my pa só omgekrap...' as sy self eintlik omgekrap voel.

Gesinslede maak ook van verplasing as verdedigingsmeganisme gebruik om hulle interne woede te kanaliseer. Só ook maak sekere gesinslede van reaksie formasie as verdedigingsmeganisme gebruik om hulle pyn te verbloem. ' $n$ Dogter noem van haar broer: '...hy het nie gehuil nie, hy het grappies gemaak, hy het gesels...' Tog is dit duidelik dat hy die ervaring baie diep beleef as sy sê dat: ...hy is baie stil, hy praat glad nie daaroor nie...' en maak hy dus van suppressie as verdedigingsmeganisme gebruik

Sommige gesinslede identifiseer met die pasiënt en dit maak besluitneming oor onttrekking van behandeling vir hulle soveel moeiliker: 'Sy het altyd vir ons gesê, jy weet, sy is bang om dood te gaan, sy wil nie doodgaan nie... Nou dit bly by my, want ek voel ook so daaroor. Presies soos my ma daaroor gevoel het...'

Gesinslede maak ook van intellektualisering as verdedigingsmeganisme gebruik om hulle pyn en hartseer met hulle verlies van die pasiënt, met positiewe herinneringe te verwoord. Die dogter vertel hoe sy haar gedistansieer het van haar emosies om kognitief ' $n$ besluit te kon neem. '...Dis eerlikwaar nie lekker, om daar te staan en jy kyk na die 
man wat jou grootgemaak het... hy was ' $n$ wonderlike pa, hy't altyd sy bes vir jou gedoen... Dit is hoekom, jy sluit jou emosioneel af en jy begin klinies daarna kyk en jy probeer die besluit so neem...'

Gesinslede maak ook van rasionalisasie gebruik deur aanvaarbare redes vir hulle gedrag te soek, so kan hulle die werklike onaanvaarbaarheid van die situasie verdring: 'Dit was sy strepie en hy moes maar net gaan. Mens redeneer mos maar só...' en '...dinge het ' $n$ doel. Alles het ' $n$ doel, en daarom, ek moet berus daarby...' Hardin (1980:27) noem ook dat wanneer emosies betrokke is, is dit verskriklik belangrik om tussen die lyne te lees.

Dit pla ook gesinslede dat hulle dit moeilik vind om hulle emosies te wys: 'Dit is vir my die ergste dat ek nie kan huil nie en ek kan nie verstaan hoekom kan ek nie huil nie.' Thompson (1979:41) vind dat daar ' $n$ verband is tussen die onvermoë om te huil en die amper kompulsiewe behoefte om te praat, en vind dat mense is beter - oor hulle rouproses, wanneer hulle nie meer so baie praat nie.

Wanneer die pyn van verlies en hartseer te veel word vir die gesinne in die onderhoude, defokus hulle na minder pynlike dinge.

\section{Emosionele}

belewenisse rondom

besluitneming

\section{Magteloosheid en hulpeloosheid} word deur gesinslede op verskillende wyses uitgespreek: 'Jy kan vir niemand verduidelik hoe voel dit om daar te sit en na daardie masjiene te kyk en jy weet... enige manier, enige sekond, gaan haar hart nou ophou...'

Ook die onsekerheid oor die pasiënt se toestand wat baie fluktueer, skep verwarring by gesinslede oor die neem van die besluit: '...jy kan nie vir daardie persoon sê: stop dit nie, want jy weet nie wat gaan gebeur nie. Daar het sy soveel keer gedraai en gedraai, dan lyk sy beter en dan lyk sy slegter... ' Cantor (1987: 108109) sê daar is kommer dat verwardheid, vrees, en algemene emosionele onsteltenis sal inmeng met die vermoë van die gesin om ' $n$ goeddeurdenkte besluit te neem.

Afwagting maak ook ' $n$ groot deel van die gesinne se belewenis uit in die tyd wat die pasiënt in die intensiewesorgeenheid lê. 'Daai gewag, dit het my klaar gemaak...'

Gevoelens van vrees word deur verskeie gesinslede beleef. Dit wat gevrees word varieer egter van persoon tot persoon,

maar draai hoofsaaklik rondom die dood of sterwensproses, soos die doodsvrees van die pasiënt en haar dogter wat reeds beskryf is. Dié dogter spreek ook haar vrees vir skuldgevoelens uit om ' $n$ besluit te neem: '...ek as persoon sou myself nooit vergewe in die lewe as ek moes vir hulle gesê het stop daardie storie nie....'

'n Dogter vertel van haar vrees dat sy te laat sou wees om finaal haar ma te groet. Angs word ook deur gesinslede ervaar met die aanskoue van die pasiënt se toestand, soos wat die vrou van 'n pasiënt vertel: 'Oee!!! Dit was vir my verskriklik. Ek't naderhand die suster gaan roep, want toe begin ek benoud word...'

Uit die analise van data, het ek en die onafhanklike kodeerder agter gekom dat die gesinne baie woede en verwyte ervaar. Sommige gesinslede ervaar woede teenoor die pasiënt omdat hulle alleen agterbly. 'Ek was regtig baie kwaad vir hom!!! En ek het vir hom gesê: kyk hier (in lykshuis) lê jy nou... en wat van my? Ek was regtig, baie kwaad vir hom!!!' Gesinslede beleef ook innerlike konflik in hulle woede teenoor God met hulle verlies van die pasiënt.

\section{Gevoelens van vrees word deur verskeie gesinslede beleef.}

\begin{abstract}
'n Dogter vertel van personeel se reaktiewe woede en haar woede met die onsensitiwiteit van die personeel: 'Toe sê die suster vir my: kan ek nie lees nie. Besoektye, en sy het nog haar vinger so getik teen die bord, is half agt tot half nege. Toe klap sy die deur toe.... Ek was baie vies!!!'
\end{abstract}

Verwyte word ook deur sommige gesinslede in die algemeen geopper en woede word openlik deur gesinslede uitgespreek teenoor dokters wat nie openlik en eerlik ten opsigte van die pasiënt se toestand is nie. Czerwiec (1996:32) vind ook dat die hoogste graad van ongelukkigheid was van gesinne wat gevoel het dat hulle nie op hoogte van sake gehou is rakende hulle geliefde se toestand nie.

Gesinslede ervaar ook gevoelens van deernis teenoor die pasiënt: '...die ander menslike sy van my voel 'n verskriklike deernis vir hom, jy weet, dat 'n mens so uitgelewer moet wees aan die genade van jou eie familie...

Oomblikke van hartseer word in die onderhoude met die gesinslede beleef.
Hierdie emosionele belewenisse laat hulle ongemaklik voel en van hulle verdedigingsmeganismes gebruik maak soos wat reeds bespreek is.

Gevoelens van alleenheid, leegheid, verlange en ' $n$ gevoel van verlies - ' $n$ gemis, word ook deur gesinslede beskryf. Die onvermydelike finaliteit van die situasie, dring ook uiteindelik tot gesinslede deur: '...jy weet, dit is so finaal! Klaar! En jy kan vir haar absoluut nie ' $n$ ding doen nie. Dit is die ergste...

\section{Behoefte aan kennis/} persepsies/lewensbeskouings/ interne konflik/skuldgevoelens/ vermoë of onvermoë om ' $n$ besluite te neem/respek vir pasiënt se wense/die rol van tyd en vorige envaring

'n Gebrek aan kennis of misverstande is volgens Edwards (1994:54) dikwels die oorsaak dat ' $n$ gesin nie met personeel saamstem oor wat die beste vir die pasiënt is nie.

Meeste gesinslede in hierdie studie openbaar ook ' $n$ behoefte aan kennis oor die pasiënt se toestand : '...jy as persoon, $j y$ het nie mediese kennis nie. Hoe moet iy nou weet? Wat is beter en wat is nie...?' en spreek groot dankbaarheid uit teenoor verpleeg-personeel wat wel die gesin met die nodige kennis oor die pasiënt se toestand en omtrent die verskillende masjiene inlig: 'Jy hoef nie eers te gevra het wat gaan aan nie. Hy het jou gevat en vir jou verduidelik die is dit, en die is dit...

Gesinslede spreek ' $n$ behoefte uit na eerlikheid en openlikheid, nie valse hoop nie, vanaf die dokters sodat hulle as gesin vroegtydig ' $n$ goedingeligte besluit kan neem. '... ek is seker die dokters kon vroeër al vir ons gesê het. Jy weet, hulle probeer jou moed inpraat maar vir my is dit meer skadelik... ek kan voel daar's iets wat hulle vir my wegsteek, en dit maak my kwaad!! Jy weet, dit is asof hulle verwagtings by jou skep om jou sterk te hou of moed in te praat. ' $n$ Mens soek dit nie!

Dit blyk verder uit hierdie studie dat gesinslede voel dat 'n direkte antwoord of besluit deur die dokter, sou dit vir hulle makliker maak om ' $n$ besluit te neem: ' as daardie ou (dokter) vir jou sê... daar is fisies niks wat hulle vir haar kan doen nie... liewers stop hierdie goed...'Beauchamp \& Perlin (1978:173) vind die gesin is dikwels verlig as die totale verantwoordelikheid van die besluit nie op hulle rus nie. 
Dit is asof sekere van die gesinslede dit makliker vind om ' $n$ besluit te neem en die verantwoordelikheid daarvoor te neem as ander en dan ondersteun hulle ook die ander gesinslede in dié opsig. Gesinslede skram ook weg van verantwoordelikheid vir die neem van die besluit.

Dis asof daar minder skuldgevoelens oor die besluit wat geneem is voorgekom het by die gesinne waar al die lede saamgestem het, as by die gesinslede waar die lede óf nie saamgestem het óf nie wou deelneem aan besluitneming nie.

'n Pasiënt se man het deurgaans geworstel met die volgende selfverwyt:

'...Is dit nie my skuld dat sy nou al doodgegaan het nie?' Sekere gesinslede ervaar ook morele konflik met die neem van ' $n$ besluit en dink selfs dis immoreel om só ' $n$ besluit te moet neem: '...ek kan nie eens dink dat hulle so iets van mens kan verwag nie...' Hierteenoor voel ander: 'Vir my was dit maar net iets onafwendbaar wat gekom het op die tyd wat dit moes gekom het...' Ander morele konflik met die neem van ' $n$ besluit is: ' $E k$ het ná die besluit vir my dogter gesê: sal ek nie nou as ' $n$ moordenaar opgeneem word nie?'

Die persepsies oor pyn en lyding wat die gesinslede het asook hulle lewensbeskouings oor die kwaliteit van lewe verskil soos in die volgende aanhalings gesien kan word: '...sy kan vir nog tien jaar gelê het. Dit pla my nie... net om te weet haar hart klop nog en sy is by ons...' hierteenoor voel ander gesinslede: '...dis al wat haar aan die lewe hou, die adrenalien wat haar hart aan die klop hou...'

In hierdie studie het gesinne verskillende persepsies gehad, veral ten opsigte van pyn en lyding wat die pasiënt mag ervaar, wat ook hulle besluitneming beinvloed het. Dit het duidelik geword dat lede van die gesinne wat nie gereeld (of glad nie) die pasiënt besoek het nie, die persepsie het dat die pasiënt nie ly nie: '...jy weet, op daardie stadium het sy nog nie gely nie...' Terwyl die gesinslede wat die pasiënt amper elke dag besoek het en baie tyd by die hospitaal saam die pasiënt deurgebring het, die persepsie het dat die pasiënt ly: '...hoekom moet my man so lê en ly.... as hulle vir hom niks kan doen nie...'

Gesinslede wat van die persepsie is dat die pasiënt ly wil ook graag die lyding laat beindig kan hulle is ook meer bereid om die verantwoordelikheid vir die besluit te neem en wil die ander gesinslede 'oortuig' dat dit die regte besluit is om behandeling te onttrek: 'En dit was ook aan die einde van die dag ek wat vir hulle gesê het: Dit help nie om my pa op die

\section{Sommige gesinslede identifiseer met die pasiënt en dit maak besluitneming oor ontrekking van behandeling vir hulle soveel moeiliker}

niermasjien te sit nie... Dit gaan net sy lyding verleng...

Kirschbaum (1996:56-57) bevind in sy studie dat gesinne in al die gevalle beskryf dat hulle nie wil hê dat die pasiënt langer toegelaat moet word om te ly nie en is kenmerkend sensitief is vir wat die pasiënt gevra het of projekteer wat die pasiënt sou wou gehad het.

Gesinslede laat hulle ook lei in besluitneming deur die wense van die pasiënt te respekteer. '... as hy moes weet dat hy só moes gely het, sal hy my kwalik geneem het, want hy't altyd gesê: Hy wil nie hê hy moet aan masjiene en goed gekoppel wees nie...'

Gesinslede dui aan dat vorige ervaring met die dood of sterwensproses ook hulle besluitneming beinvloed het. Dit kom vir my voor asof die gesin 'n groter behoefte aan ondersteuning en begeleiding met die sterwensproses het as hulle geen verwysingsraamwerk het om op terug te val nie. '... maar ons ken nie so iets nie... Vir ons was dit ' $n$ first time experience...' My vermoede word bevestig deur: '...tien jaar terug het ekmy broer verloor... dit was baie skielik gewees... Jy het nie daai kans gehad om jou mettertyd voor te berei met wat kom nie... My pa se senario was heeltemal anders... Uhm, en ek persoonlik verkies dat wat ons daai twee weke as ' $n$ familie saam deurgegaan het...'

\section{- Ondersteuning ontvang en benodig deur die gesin wat betrokke is by besluitneming}

Die werksomgewing word deur lede in albei gesinne as ondersteuningsbron beskryf: '...jyweet, soos ek vir die vrouens ook gesê het by die werk: jy kan nie vir iemand beskryf hoe voel dit..."

Gesinslede ondersteun mekaar onderling met die neem van die besluit oor onttrekking van behandeling soos wat ' $n$ dogter haar ma voorberei op wat kom as sy vir haar sê: '... hy gaan nie hier opstaan nie en die feit, ek het dit vir my ma gesê ook en ek het gesien: sy wil dit nie weet nie, so ek het gedink, miskien moet ek stelselmatig net vir haar begin sê: die probleem hier is regtig : my pa gaan nie hier opstaan nie...'

Die gesin ondesteun ook die pasiënt in die tyd wat hy/sy in die intensiewesorgeenheid lê: '... ons was permanent by haar gewees... Net om by haar te wees, net dat sy geweet het... iy is daar...' Gesinslede ondersteun die pasiënt ook met gebede: '... en ek het gegaan, ek het daar gaan bid by haar...' Ander familie speel ook ' $n$ belangrike rol in ondersteuning vir die gesinne en die pasiënte in hierdie studie. Ook Kirschbaum (1996:61) vind in sy studie dat die familie in geheel ' $n$ belangrike sosiale ondersteuningstelsel is vir die gesin.

Gesinslede toon ook begrip en medelye met mekaar se gevoelens en voel dat hulle as gesin nader aan mekaar beweeg en gedagtes en gevoelens deel in die tyd wat hulle ' $n$ besluit moes neem oor onttrekking van lewensondersteunende behandeling by die pasiënt. Thompson (1979:31-32) noem in sy boek dat die gesamentlike belewing van die sterfgeval deur die gesin ' $n$ belangrike wyse van rou is.

Verpleegpeersoneel en dokters wat ondersteuning aan die gesin bied word baie positief deur die gesinne beleef: 'Hulle is net fantasties en hulle het ons so geondersteun en so gehelp en alles...' Ook personeel wat emosie toon en bewys en belangstelling in die pasiënt en die gesinslede toon word baie waardeer en onthou deur gesinslede: ...daardie ou suster wat daar in ICU is, elke aand dan het sy my gestop daar en vir my kom vra hoe gaan dit ... en daardie aand toe sy ( pasiënt) dood is, toe sy dit hoor - daardie vroumens het so gehuil saam met my...'

Czerwiec (1996:33) noem dat die sorg en ondersteuning wat personeel aan die sterwende se geliefdes gee en die klein dingetjies wat hulle doen, van ontelbare waarde vir die gesin is. Gesinslede in hierdie studie waardeer ook dat personeel hulle behoeftes raaksien en daarin probeer voorsien.

Beide gesinne in hierdie studie noem dat hulle en die pasiënt in ' $n$ mindere of meerdere mate ondersteuning van die kerk gekry het: 'So hy (dominee) was daar en hy het vir ons ondersteuning gebied... Nie raad gegee nie, maar geluister en gefasiliteer die proses, maar dit is goed dat daar iemand is wat jy weet, wat ten minste ' $n$ stukkie uit die Bybel lees en bid iy weet, vir die regte leiding...' Volgens Thompson (1979:21-22) kan die dominee deel in die sterwensproses, gesinne help om die situasie te hanteer en hulle ondersteun tydens die periode 
voor die dood.

Ten spyte van al die ondersteuning wat die gesinne wel uit die verskillende oorde ontvang het, het meeste van die gesinslede ook ' $n$ duidelike behoefte na konsultasie/ondersteuning uitgespreek in die tydperk wat hulle verward en emosioneel is: 'Ek sal ook net sê hulle moet iemand hê daar om met ' $n$ familie te kan praat... ' $n$ mens ' $n$ bietjie kan voorberei...' Hulle spreek ook groot dankbaarheid uit teenoor personeel wat wel in die behoefte voorsien: '...toe sit sy nou met my en gesels... Nou dit is dinge daardie wat 'n mens na aan die hart lê... Dit help jou deur 'n moeilike tyd...'

Gesinslede in hierdie openbaar ook ' $n$ behoefte om hulle belewenisse te deel met die onderhoudvoerder.

Geestelike en mistieke belewenisse /hoop/berusting en aanvaarding / vermoë om 'te laat gaan' of 'los te maak' van die pasiënt

Hoop word deur Dufault \& Martocchio (1985: 379-391) beskryf as die breë abstrakte emosie wat beskerming bied teen wanhoop. Dit is asof hoop sterkte gee aan die individu. Aanvanklik, tydens die ontkenningsfase, in hierdie studie, het meeste van die gesinslede gehoop en gebid vir herstel by die pasiënt: '...jy weet, jy hoop maar hier binne, hoop en bid hulle is nie reg nie...' Saam met die hoop het ook altyd weer vertwyfeling gekom: '...dan kom daai teenstrydige gevoelens op...'

Van die gesinslede plaas hulle vertroue op die tegnologie en hoop om die pasiënt se lewe so te verleng: '...ek het regtig gedink met die niermasjiene en alles sou sy regkom...', terwyl ander die beperkinge van die tegnologie gou reeds besef: '...ek het wel geweet my pa sou sterf, al word 'n dialisemasjien of alles wat daarmee saamgaan...'

Met verloop van die proses het die finaliteit tot die gesinslede begin deurdring en het hulle gehoop vir pynvryheid en gemak vir die pasiënt: '... want ek't geweet die lyding wat vir hom voorlê... En mens hoop maar net en bid maar net hy was nie bewus van enige iets nie...' Coulter (1989: 4-10) vind in sy studie dat selfs wanneer hoop op herstel verby is, heers daar hoop vir ' $n$ vredevolle en pynvrye dood.

Dis asof sommige gesinslede selfs in onderhandeling 'bargaining' met God wil tree en uiter hulle pleidooie om beterskap en om lyding te verlig. ' $n$ Dogter vertel toe haar broer hoor sy ma se einde is naby: '...toe het hy gebid en gevra: Hy moet haar net hou tot hy daar kom...' Die dogter lewer ook 'n pleidooi aan haar moeder: '...ek het haar nog so mooi gevra: wys hulle... Laat dit vir hulle 'n wonderwerk wees. Wys hulle ma kan regkom...'

Teen die einde hoop gesinslede egter vir laaste nabyheid met die pasiënt en sommiges bid ook vir die pasiënt. '...toe wil ek haar sien so lank as wat ek kan...' en '...ek hoop en bid sy het my verstaan, want al die gebede wat ek gedoen het vir haar, hardop moes sy gehoor het...'

Baie van die gesinslede hoop ook nog op wonderwerke om te gebeur: ....wonderwerke is nog lank nie verby nie. Daar kan enige iets gebeur...' Alhoewel
Gesinslede uit beide gesinne vertel dat die pasiënt ' $n$ voorgevoel gehad het dat hy/sy gaan sterf: '... hy het dikwels vir my gesê: Ag, ou Koos se tyd is in elk geval naby. Volgens Beauchamp \& Perlin (1978:161) stem waarnemers saam dat ' $n$ pasiënt wat siek genoeg is om te sterf, dit dikwels weet sonder dat dit vir hom gesê hoef te word.

Gesinne meld ook ' $n$ 'mistieke ervaring' en/of 'n vreemde belewenis' wat hulle gehad het in die tydperk wat die pasiënt in die intensiewesorgeenheid was en hulle ' $n$ besluit moes neem oor onttrekking van behandeling soos ' $n$ vrou van ' $n$ pasiënt vertel: :...ek het meteens gevoel ' $n$ yskoue wind het vanaf my regterkant af, agter by my rug en nek verby

\section{... onsekerheid oor die pasiënt se toestand wat baie fiuktueer, skep verwarring by gesinslede oor die neem van die besluit ...}

gesinslede op wonderwerke en die natuur vertrou voel meeste dat die besluit nie werklik in hulle hande is nie en dra hulle die pasiënt op aan die Hoër Hand.

...jy laat die natuur sy gang gaan en dis nou God se besluit. Jy gee hom nou vir God...

Van die gesinslede beleef ook ' $n$ geloofstryd soos gesien as 'n pasiënt se man se priester hom help om sy interne stryd met sy geloof aan die een kant en sy onwilligheid om sy vrou 'te laat gaan' aan die anderkant, uit te klaar. '... Toe sê hy (priester) vir my: nee, dis jou plig om dit te doen as huispriester om vir haar te sê $j y$ is tevrede om haar te laat gaan...' en '... en ek het vir haar gesê: sy moet nie bang wees nie... Ek as persoon sal haar nie laat gaan nie, maar as dit die Here se wil is dan moet Hy haar vat...' Die konflik is egter nog sigbaar in sy woorde dat hy voel sy vrou word 'gevat' en dat hy nog nie werklik gereed is om 'te laat gaan' nie.

Teen die einde van die proses het ek en die onafhanklike kodeerder opgemerk dat verloop van tyd ruimte gebied het vir berusting en aanvaarding en dat die gesin begin 'los maak' van die pasiënt. '... Ons het al soort van ' $n$ week of paar dae voordat hy dan nou gester het, het ek my al... begin in ' $n$ mate begin (losmaak)... ek het dit al beter aanvaar...'

Uiteindelik berus meeste van die gesinslede ook in die dood van die pasiënt en glo dat hy/sy gelukkig en pynvry sal wees: ‘...dan glo ek sy (pasiënt) berus daarby en dit is hoekom ek vandag, ek berus my daarby dat sy sal gelukkig wees...' gegaan... daar was geen vensters of deure in ICU dat dit dit kon wees nie... toe my seun en dogter nou inkom, vertel ek hulle. Toe het my seun vir my gesê dis die doods engel wat... hy dink dis die engel wat sy pa kom haal het... En hy's (pasiënt) daai selfde nag, ses ure daarná, oorlede, of het hy opgehou asemhaal...

Die gesinne ervaar uiteindelik die werklike afsterwe van die pasiënt vredevol, en deel hierdie belewenis as gesin (en familie wat teenwoordig is) saam. Verskeie gesinslede noem dat hulle bly is dat hulle nie op die oomblik van die afsterwe teenwoordig was nie, maar dat hulle dankbaar is dat hulle tyd gegun is om finaal te groet soos wat ' $n$ dogter verduidelik: 'Dit is so uniek! So spesiaal! Jy ervaar geen skok nie... dis eerder die volmaakte afs/uiting van wat $j y$ vir twee weke lank saam as 'n familie deurgegaan het... Jy weet, dis half so vredevol gewees...'

Vervolgens was riglyne beskryf vir die psigiatriese verpleegspesialis om hulpbronne te mobiliseer wat sal bydra tot die bevordering, handhawing en herstel van die gesin se geestesgesondheid as integrale deel van gesondheid.

\section{Riglyne aan Psigiatriese Ver- pleegspesialiste}

Die temas verkry uit die sekondêre analise van data uit die studie van Burger (1996: 1-175), data verkry uit analise van die fenomenologiese onderhoude met 
die lidkontrole gesinne en die literatuurkontrole, is gebruik in die beskrywing van die riglyne vir die psigiatriese verpleegspesialiste wat met die gesinne werk.

Die temas reflekteer die kenmerkende wyses van interaksie in die omgewing binne die Verplegingsteorie vir Menslikheid (Oral Roberts University: Anna Vaughn School of Nursing, 1990: 136-142).

Baggs (1993:108-112), Beauchamp \& Perlin (1978), Czerwiec (1996:32-37), Edwards (1993:33-38; 1994:52-57), Kirschbaum (1996:51-71), Vergara \& Lynn-McHale (1995:47-50) en Zerwekh (1994:30-35) gee in hulle studies riglyne, wat gebruik kan word deur die psigiatriese verpleeg- spesialis in haar strewe om gesinne in hierdie situasies te help, wat ek vervolgens in 'n samevatting sal bespreek.

Voorsien in die liggaamlike en fisieke behoeftes van die gesin (en die pasiënt - hulle geliefde) soos wat hulle dit benodig en nie soos wat jy dink hulle dit benodig nie.

Betrek lede van die gesin wat 'n behoefte daarna het, by die versorging van die pasiënt - dit laat hulle minder uitgesluit voel. Moedig fisiese kontak tussen die gesin en die pasiënt aan - dit help die gesin om moontlike gevoelens van woede of skuld deur te werk en hulle liefde aan die pasiënt te betoon. Voorsien in die fisieke behoeftes van die gesin deur 'n omgewing te skep waarin hulle emosioneel en psigies gemaklik en veilig kan voel - so kan jy hulle ervaring met die sterwens- proses so positief moontlik maak.

Let op verdedigingsmeganismes wat die gesinslede gebruik en help hulle om in kontak met hulle eie emosies te kom.

Hoe meer gereeld gesinslede die pasiënt in sy/haar toestand sien, hoe groter is die kans dat hulle ontkenning sal ophef en die realiteit van die situasie sal insink. Luister onveroordelend na gesinslede sodat hulle hul emosies kan ventileer en gee dán eers die belangrike inligting wat hulle benodig om ' $n$ besluit te maak. Moet nooit ' $n$ 'sledge hamer' metode gebruik om die gesin tot die waarheid te forseer nie, maar bly daarop toegespits om die waarheid te vertel. Bou ' $n$ vertrouens verhouding op - so kan jy dalk ook die patroon van intellektualisering en rasionalisering verbreek en begin om moeilike vrae te vra en die woorde te sê wat gesê moet word. Hou pasiënte gefokus op hulle emosies as hulle defokus en lees tussen die lyne, veral waar emosies betrokke is, is mense geneig om te rasionaliseer - help hulle in kontak met hulle emosies kom.

Voorsien gesinslede met die hoeveelheid emosionele steun wat hulle werklik nodig het en nie met hoeveel jy dink hulle nodig het nie.

Onthou dat die gesin deur ' $n$ krisis gaan en dat baie sterk emosies normaal is. Bou 'n vertrouensverhouding op met die gesin deur jou besorgdheid met die pasiënt en gesin te toon en sodoende ' $n$ emosionele band te bou. Laat gesinslede toe om hul woede, pyn en hartseer te ventileer en luister aandagtig. Ondersteun die gesin as hulle emosioneel is deur hul hand te hou of ' $n$ sagte druk op die skouer - weet ook wanneer om hulle alleen te laat in hulle verdriet. Help gesinslede deur hulle skuldgevoelens, selfverwyte, hartseer en die rouproses werk deur onder-steunend te luister waar nodig.

Voorsien die gesin met die nodige kennis om ' $n$ ingeligte besluit te kan neem en stel die pasiënt - en gesinswense vas sodat jy kan help om dit te implementeer.

Dit is belangrik om die gesin te leer van die pasiënt se toestand in verstaanbare taal. Wees ook altyd eerlik en reguit in die beantwoording van vrae omtrent die prognose van die pasiënt sodat die gesin 'n verantwoordelike besluit kan neem. Moet nooit valse hoop en versekering vir die gesin gee nie. Evalueer deurlopend die gesinslede se vermoë om die besluitnemingsproses te kan hanteer en gee die nodige ondersteuning en berading/begeleiding. Skep genoeg geleenthede en tyd vir die gesin om met die hele gesondheidspan oor die pasiënt se behandeling te beraad. Om gesinne te help om ' $n$ besluit te neem, mag beteken om hulle eers te help om met mekaar te kommunikeer - wees sensitief vir die tydstip van bespreking. Wanneer die pasiënt nie die besluit kan maak nie, behoort dit gedoen te word deur die persoon wat die pasiënt aangewys het of deur gesinslede wat die pasiënt voorkeure ken of wat in die pasiënt se beste belang optree. As die waarheid vertel is en die gesin ' $n$ besluit geneem het, het hulle dikwels hulp nodig om hulle keuses deur te voer, veral as hulle teenkanting van die medici kry.

Skep ' $n$ sterk persoonlike ondersteuningsraamwerk of stelsel vir die gesin.

Betrek ander familie, kollegas, vriende en ander betekenisvolle ander om die gesin te ondersteun en om te help waar fisieke probleme mag opduik. Help gesinslede om onderlinge verskille en konflik deur te werk, om as gesin deur die sterwensproses te werk, om mekaar te kan ondersteun en op mekaar se behoeftes ingestel te wees. Wees beskikbaar vir die gesin en luister onveroordelend. Waar moontlik kan ondersteuningsgroepe met ander gesinne in soortgelyke situasies gehou word.

Erken en voorsien in die behoefte aan geestelike ondersteuning.

Roep ' $n$ dominee of geestelike berader van die gesin en pasiënt se keuse in waar daar ' $n$ behoefte blyk te wees of jy kan dit bied as hulle dit so verkies en jy gemaklik daarmee is. Ondersteun die gesin in die sterwensproses deur jou teenwoordigheid en betoon Christelike liefde en sorg aan die gesin en pasiënt. Bied geleentheid aan die gesinslede wat dit só verkies om by te staan in die afsterwe en gee genoegsame tyd om die pasiënt te groet. Wees altyd beskikbaar met sorg en ondersteuning.

\section{Begrip van die verskynsel van gesinne wat betrokke is by besluitneming oor onttrekking van lewensondersteunende behandeling, kan as basis dien vir die beskrywing van riglyne vir die psigiatriese verpleegspesialis om hulpbronne te mobiliseer vir dié gesinne ter bevordering, handhawing en herstel van hulle geestesgesondheid as integrale deel van hul gesondheid.}




\section{BRONNELYS}

BAGGS, J.G. 1993. Collaborative interdisciplinary bioethical decision making in intensive care units. Nursing Outlook, 41 (3): 108 112. Jan/Feb.

BEAUChAMP, T.L. \& PERLIN, S. 1978. Ethical issues in: death and dying. New Jersey: Prentice Hall.

BOTES, A.C. 1989. 'n Model vir wetenskapsbeoefening in die verpleegkunde. (D.Cur. Proefskrif). Johannesburg : Randse Afrikaanse Universiteit.

BURGER, G. 1996. Faktore in besluitneming oor lewensondersteunende behandeling. (M.Cur. Skripsie). Johannesburg : Randse Afrikaanse Universiteit.

BURNS, N. \& GROVE, S.K. 1993. The practice of nursing research: conduct, critique and utilization. USA : W.B. Saunders Company.

CANTOR, N.L. 1987. Legal frontiers of death and dying. USA : Indiana University P.ress.

COULTER, M. 1989. The needs of family members in ICU's. (In WILKINSON, P. 1995. A qualitative study to establish the selfperceived needs of family members of patients in general intensive care units.) Intensive and Critical Care Nursing,11:77-86.

CZERWIEC, M. 1996. When a loved one is dying: families talk about nursing care. American Journal of Nursing, $96(5): 32-37$.

DUFAULT, K. \& MARTOCCHIO, B.C. 1985. Hope, its spheres and dimensions. (In WILKINSON, P. 1995. A qualitative study to establish the selfperceived needs of family members of patients in general intensive care units) Intensive and Critical Care Nursing, 11:77-86.

EDWARDS, B.S. 1994. Ethical issues: when the family can't let go. American Journal of Nursing. 94(1):52-57. Jan.

HARDIN, G. 1980. Promethean ethics:living with death, competition and triage. Seattle : University of Washington Press.

KIRSCHBAUM, M.S. 1996. Life support decisions for children: what do parents value? Advances in Nursing Science, 19(1):5171. Sep.

KREFTING, L. 1991. Rigor in qualitative research: the assessment of truthworthiness. The American Journal of Occupational Therapy, 45(3):214-222. Mar.

MORRIS, M.K. 1992. Moral conflicts and ordinary emotional experience. Journal of Value Inquiry, 26(2):232-237.

ORAL ROBBERTS UNIVERSITY, ANNA VAUGHN SCHOOL OF NURSING, 1990. Self-study report, submitted to the Council of Baccalaureate and Higher Degree Programs, National League for Nursing, August 1990. Volume 1 - Narrative by Criteria. Tulsa, Oklahoma : Oral Roberts University AnnaVaughn School of Nursing.

THOMPSON, I. 1979. Dilemmas of dying: a study in the ethics of terminal care. Edinburgh : T.\&A. Constable.

VERGARA, M. \& LYNN-McHALE, D.J. 1995. Ethical issues: withdrawing life support: who decides? American Journal of Nursing, 95:47-50. Nov.

ZERWEKH, J. 1994. The truth-tellers: how hospice nurses help patients confront death. American Journal of Nursing, $30-35$. Feb. 